\title{
The Achievement of a Zinc Oxide-Based Homojunction Diode Using Radio Frequency Magnetron Cosputtering System
}

\author{
Hung-Jen Chiu, ${ }^{1}$ Tai-Hong Chen, ${ }^{2}$ Li-Wen Lai, ${ }^{2}$ Ching-Ting Lee, ${ }^{3}$ \\ Jhen-Dong Hong, ${ }^{1}$ and Day-Shan Liu ${ }^{1}$ \\ ${ }^{1}$ Institute of Electro-Optical and Materials Science, National Formosa University, Yunlin 63201, Taiwan \\ ${ }^{2}$ ITRI South, Industrial Technology Research Institute, Tainan 73445, Taiwan \\ ${ }^{3}$ Institute of Microelectronics, National Cheng Kung University, Tainan 70101, Taiwan \\ Correspondence should be addressed to Day-Shan Liu; dsliu@nfu.edu.tw
}

Received 18 September 2014; Accepted 16 March 2015

Academic Editor: Giuseppe Compagnini

Copyright (C) 2015 Hung-Jen Chiu et al. This is an open access article distributed under the Creative Commons Attribution License, which permits unrestricted use, distribution, and reproduction in any medium, provided the original work is properly cited.

\begin{abstract}
$(\mathrm{Al}+\mathrm{N})$-codoped $p$-type zinc oxide $(\mathrm{ZnO}) /$ undoped $n$-type $\mathrm{ZnO}$ homojunction structure was deposited onto $\mathrm{Si}$ (100) substrate by using radio frequency (rf) magnetron cosputtering system. Transparent indium tin oxide (ITO)-ZnO cosputtered film was employed as the ohmic contact electrode to the $n$-type $\mathrm{ZnO}$ film, and the specific contact resistance was optimized to $2.9 \times$ $10^{-6} \Omega \mathrm{cm}^{2}$ after treating by a rapid thermal annealing (RTA) process at $400^{\circ} \mathrm{C}$ for $5 \mathrm{~min}$ under vacuum ambient. The ohmic contact behavior between the metallic $\mathrm{Ni} / \mathrm{Au}$ and $p$-ZnO film also was improved to $3.5 \times 10^{-5} \Omega \mathrm{cm}^{2}$ after annealing at $300^{\circ} \mathrm{C}$ for $3 \mathrm{~min}$ under nitrogen ambient. The interfacial diffusion of these ohmic contact systems which led to the optimization of the specific contact resistances by the RTA process was investigated by the Auger electron spectroscopy (AES) depth profile measurements. The diode characteristics of the resulting $p-\mathrm{ZnO} / n-\mathrm{ZnO}$ homojunction structure realized with these ohmic contact electrodes were confirmed by current-voltage $(I-V)$ measurement, which performed a forward turn-on voltage of $1.44 \mathrm{~V}$ with a reverse current of $1.1 \times 10^{-5} \mathrm{~A}$ at $-2 \mathrm{~V}$.
\end{abstract}

\section{Introduction}

Zinc oxide $(\mathrm{ZnO})$ with a wide and direct band gap $(\sim 3.37 \mathrm{eV})$ is one of the most promising materials used in shortwavelength optoelectronics applications [1-5]. The excellent physical and chemical properties, resistance to radiation damage, and possibility of wet-etching processes for the $\mathrm{ZnO}$ material are expected to be brighter than the current state-of-the-art gallium nitride-based (GaN-based) material. Besides, the critical advantage of the $\mathrm{ZnO}$ over $\mathrm{GaN}$ material is the technologies required for depositing quality $\mathrm{ZnO}$ films, such as sputtering, pulse laser deposition, and hydrothermal method, are relatively simple and cost effective. Unfortunately, since $\mathrm{ZnO}$ material is natural $n$-type as a consequence of the compensation effect associated with the intrinsic oxygen vacancy $\left(\mathrm{V}_{\mathrm{O}}\right)$ and zinc interstitial $\left(\mathrm{Z}_{\mathrm{I}}\right)$ donors, the preparation of the $p$-type $\mathrm{ZnO}$ film with a high carriers is comparatively difficult, thereby limiting the development of the $\mathrm{ZnO}$-based homojunction device. As a result, the heterojunction structure using other quality $p$-type materials, such as $\mathrm{ZnTe}, \mathrm{Cu}_{2} \mathrm{O}$, and $\mathrm{GaN}$ [6-8], currently becomes the main research target. While most $\mathrm{ZnO}$-based optoelectronic devices achieved from the heterojunction structure are in principle superior to those employing homojunction structure, because of the obstacles in obtaining quality and stable $p$-type $\mathrm{ZnO}$ with high conductivity and mobility, there still has been much progress in the preparation of the $\mathrm{ZnO}$-based homojunction structure especially for the light emitting diode applications. Until now, although there have been some reports on the achievement of a $\mathrm{ZnO}$ based homojunction structure fabrication using metalorganic chemical vapor deposition, molecular beam epitaxy, pulse laser deposition, atomic layer deposition, or hydrothermal method [9-12], few studies have realized $\mathrm{ZnO}$ filmbased homojunction structure purely employing sputtering technology, which has the availability of large area deposition at a relative low temperature $[13,14]$. In our previous study, we demonstrated an $(\mathrm{Al}+\mathrm{N})$-codoped $p$-type $\mathrm{ZnO}$ film 
with a hole concentration higher than $10^{18} \mathrm{~cm}^{-3}$ using the radio frequency (rf) magnetron cosputtering system [15], which is beneficial for developing ZnO-based homojunction structure. Except for the achievement of a quality $p$-type $\mathrm{ZnO}$ film, it also is essential to optimize the ohmic contact electrodes to $n$-type and $p$-type layers, respectively, since the major loss in device performance is frequently due to high-resistance ohmic contact in case of $p-n$ homojunction structure. For the electrode contact to $n$-type $\mathrm{ZnO}$ layer, most metal structures show ohmic contact to $n$-type $\mathrm{ZnO}$ with a specific contact resistance lower than $10^{-5} \Omega-\mathrm{cm}^{2}[16-$ 18]. Furthermore, a transparent conductive oxide (TCO) film also is employed as ohmic contact electrode to substantially enhance the device transparency $[19,20]$. By contrast, similar to the metal structures ohmic contact to $p-\mathrm{GaN}$, such as $\mathrm{Ni} / \mathrm{Au}, \mathrm{Pt} / \mathrm{Au}, \mathrm{Pd} / \mathrm{Au}, \mathrm{Pt} / \mathrm{Ni} / \mathrm{Au}$, and $\mathrm{Pd} / \mathrm{Ni} / \mathrm{Au}$ [21-25], only a few bilayer and multilayer metallization schemes based on high work function metals are adaptive to obtain ohmic contact behavior as contact to $p$-type $\mathrm{ZnO}$. The metal structures incorporated with $\mathrm{Ni}$ thus have been currently employed as a promising ohmic contact electrode to phosphorous-doped $p$ type $\mathrm{ZnO}$ layer owing to the favorable transformation of the $\mathrm{Ni}$ to $p-\mathrm{NiO}$ during annealing process [26-28].

In this study, with the aim to prepare a $\mathrm{ZnO}$-based homojunction structure with quality diode performance purely using the sputtering technology, the contact resistances for the transparent cosputtered electrode contact to $n$-type $\mathrm{ZnO}$ and $\mathrm{Ni} / \mathrm{Au}$ metallic system contact to $(\mathrm{Al}+\mathrm{N})$ codoped $p$-type $\mathrm{ZnO}$ films, respectively, were firstly optimized by the rapid thermal annealing (RTA) process. The mechanism responsible for the ohmic contact formation was investigated and discussed. A quality $\mathrm{ZnO}$-based homojunction diode based on these ohmic contact systems thus was achieved as evidence of its rectifying property.

\section{Experiment}

A $300 \mathrm{~nm}$ thick, undoped $\mathrm{ZnO}$ layer was deposited on the silicon substrate by a radio frequency (rf) magnetron cosputtering system at room temperature and then annealed at $700^{\circ} \mathrm{C}$ for 30 minutes under oxygen ambient to improve the crystalline structure (hereafter denoted as $n-\mathrm{ZnO}$ ). A $200 \mathrm{~nm}$ thick, cosputtered indium tin oxide (ITO)- $\mathrm{ZnO}$ film at an atomic ratio of $33 \%[\mathrm{Zn} /(\mathrm{Zn}+\mathrm{In})$ at.\%] was deposited on the $n$-ZnO layer as the ohmic contact electrode using the transmission-line method (TLM). The detailed deposition parameters to prepare the cosputtered ITO-ZnO film by the rf magnetron cosputtering system, using ITO and $\mathrm{ZnO}$ targets, are available elsewhere [29]. Meanwhile, a $500 \mathrm{~nm}$ thick ( $\mathrm{Al}+$ $\mathrm{N}$ ) codoped $\mathrm{ZnO}$ film at a theoretical $\mathrm{Al}$ atomic ratio of $10 \%$ $[\mathrm{Al} /(\mathrm{Al}+\mathrm{Zn})$ at.\%] also was deposited onto another set of the silicon substrates by the rf magnetron cosputtering system at room temperature, using $\mathrm{ZnO}$ and aluminum nitride (AlN) targets, and then annealed at $450^{\circ} \mathrm{C}$ for 30 min under nitrogen ambient to activate the doping acceptors (hereafter denoted as $p-\mathrm{ZnO})$ [15]. $\mathrm{Ni} / \mathrm{Au}(30 \mathrm{~nm} / 10 \mathrm{~nm})$ metallic system was evaporated on the $p$ - $\mathrm{ZnO}$ film using the TLM. All the contact patterns were formed through standard lift-off technology.

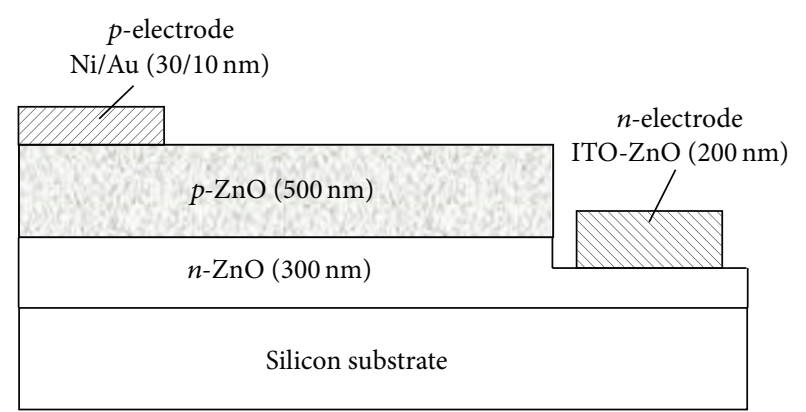

FIGURE 1: Schematic structure of the $p-\mathrm{ZnO} / n-\mathrm{ZnO}$ homojunction diode.

With the aim to optimize the contact resistance, the ITO$\mathrm{ZnO} / n-\mathrm{ZnO}$ and $\mathrm{Au} / \mathrm{Ni} / p-\mathrm{ZnO}$ contact systems were then processed by a rapid thermal annealing (RTA) treatment at temperatures ranging from $100^{\circ} \mathrm{C}$ to $500^{\circ} \mathrm{C}$ under vacuum and nitrogen ambient, respectively. Finally, a $p-\mathrm{ZnO} / n-\mathrm{ZnO}$ homojunction structure was fabricated by employing these ITO- $\mathrm{ZnO} / n-\mathrm{ZnO}$ and $\mathrm{Au} / \mathrm{Ni} / \mathrm{p}-\mathrm{ZnO}$ ohmic contact systems, as shown in Figure 1.

Film thickness was confirmed by a surface profile system (Dektak 6M). The carrier concentration and Hall mobility of the $n-\mathrm{ZnO}, p-\mathrm{ZnO}$, and ITO-ZnO films were measured using the van der Pauw method (Ecopia HMS-5000) at room temperature. The radiative emission of the $n-\mathrm{ZnO}$ and $p$ $\mathrm{ZnO}$ layers was determined from the photoluminescence (PL) spectra measured at room temperature using the $\mathrm{He}-\mathrm{Cd}$ laser $(\lambda=325 \mathrm{~nm})$ as the excitation source. Auger electron spectroscopy (AES) depth profiles of the Ni/Au metallic electrode contact to $p$ - $\mathrm{ZnO}$ film after the RTA treatment were performed on a scanning Auger nanoprobe (Ulvac-PHI, PHI 700). The current-voltage (I-V) properties of the ITO$\mathrm{ZnO} / n-\mathrm{ZnO}$ and $\mathrm{Au} / \mathrm{Ni} / p-\mathrm{ZnO}$ contact systems as well as the $p-\mathrm{ZnO} / n-\mathrm{ZnO}$ homojunction diode were measured using a semiconductor parameter analyzer (HP4156C).

\section{Results and Discussions}

Table 1 illustrates the electrical properties of the as-deposited, annealed $\mathrm{ZnO}$, and $(\mathrm{Al}+\mathrm{N})$ codoped $\mathrm{ZnO}$ films and the ITO$\mathrm{ZnO}$ cosputtered film. The as-deposited $\mathrm{ZnO}$ film behaved as an insulator with a resistivity higher than $10^{5} \Omega \mathrm{cm}$, whereas the as-deposited $(\mathrm{Al}+\mathrm{N})$ codoped $\mathrm{ZnO}$ film exhibited $n$-type conduction with electron carriers of $2.4 \times 10^{19} \mathrm{~cm}^{-3}$ due to the activation of the $\mathrm{Al}_{\mathrm{Zn}}$ donors [30]. The annealed $\mathrm{ZnO}$ film showed $n$-type conduction with an electron concentration of $3.1 \times 10^{16} \mathrm{~cm}^{-3}$ and a mobility of $19.1 \mathrm{~cm}^{2} \mathrm{~V}^{-1} \mathrm{~s}^{-1}$ as a consequence of the native donors activation and crystalline growth. By contrast, owing to the fact that the annealing process on the $(\mathrm{Al}+\mathrm{N})$ codoped $\mathrm{ZnO}$ film was favorable to activate the $\mathrm{N}_{\mathrm{O}}$ acceptors, the $(\mathrm{Al}+\mathrm{N})$ codoped $\mathrm{ZnO}$ film converted into $p$-type conduction with a high hole concentration of $1.9 \times 10^{18} \mathrm{~cm}^{-3}$. In addition, the cosputtered ITO-ZnO film employed as the transparent ohmic contact electrode to the $n$ $\mathrm{ZnO}$ layer behaved as an $n$-type degenerated semiconductor 
TABLE 1: Electrical properties of the as-deposited, annealed $\mathrm{ZnO}$, and $(\mathrm{Al}+\mathrm{N})$ codoped $\mathrm{ZnO}$ films, and the ITO-ZnO cosputtered film.

\begin{tabular}{|c|c|c|c|c|}
\hline Sample & Concentration $\left(/ \mathrm{cm}^{3}\right)$ & Mobility $\left(\mathrm{cm}^{2} / \mathrm{V}_{\mathrm{S}}\right)$ & Resistivity $(\Omega \mathrm{cm})$ & Type \\
\hline As-deposited $\mathrm{ZnO}$ & N/A & $\mathrm{N} / \mathrm{A}$ & $>10^{5}$ & $\mathrm{~N} / \mathrm{A}$ \\
\hline Annealed $\mathrm{ZnO}$ & $3.1 \times 10^{16}$ & 19.1 & 10.6 & $n$ \\
\hline As-deposited $(\mathrm{Al}+\mathrm{N})$ codoped $\mathrm{ZnO}$ & $2.4 \times 10^{19}$ & 1.2 & 0.2 & $n$ \\
\hline Annealed $(\mathrm{Al}+\mathrm{N})$ codoped $\mathrm{ZnO}$ & $1.9 \times 10^{18}$ & 3.4 & 0.9 & $p$ \\
\hline ITO-ZnO & $8.2 \times 10^{20}$ & 13.5 & $5.6 \times 10^{-4}$ & $n$ \\
\hline
\end{tabular}

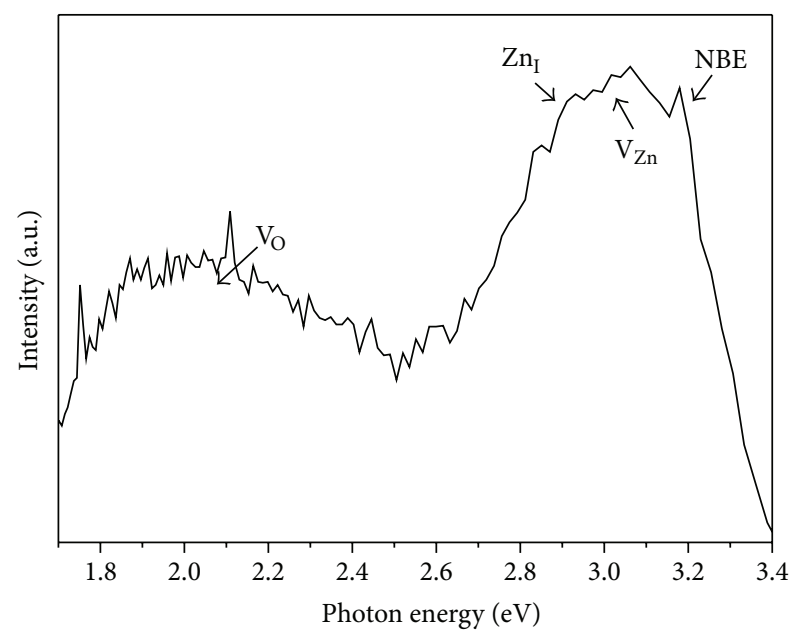

(a) As-deposited $\mathrm{ZnO}$

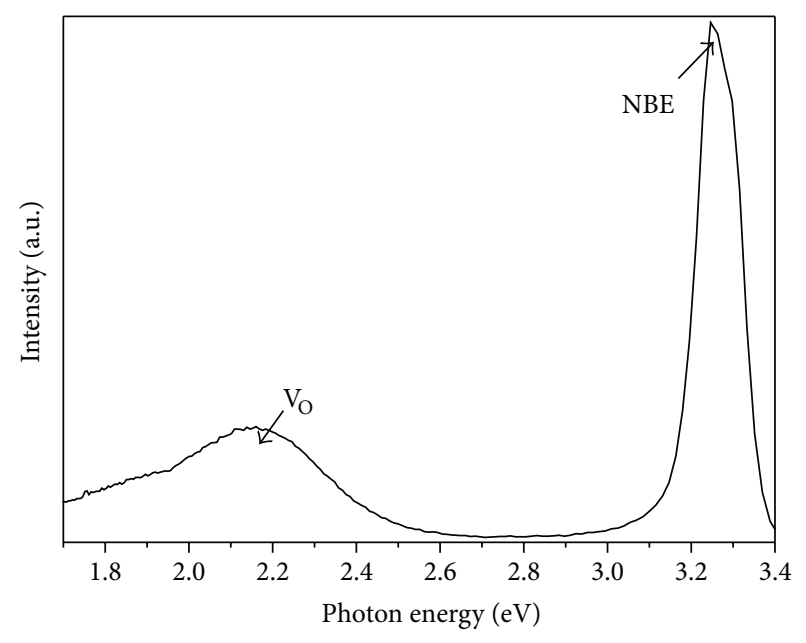

(b) Annealed $\mathrm{ZnO}$

Figure 2: Room temperature PL spectra of the (a) as-deposited and (b) annealed $\mathrm{ZnO}$ films.

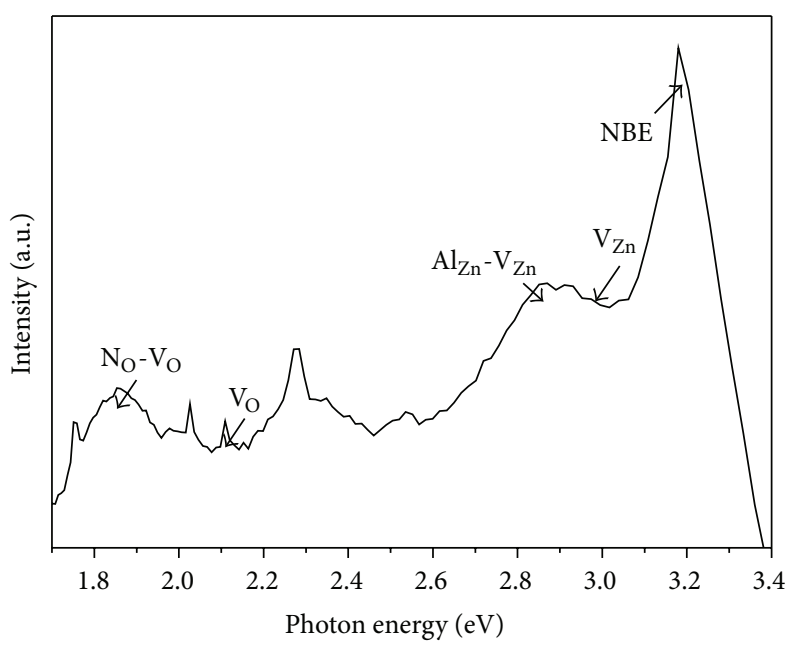

(a) As-deposited $(\mathrm{Al}+\mathrm{N})$ codoped $\mathrm{ZnO}$

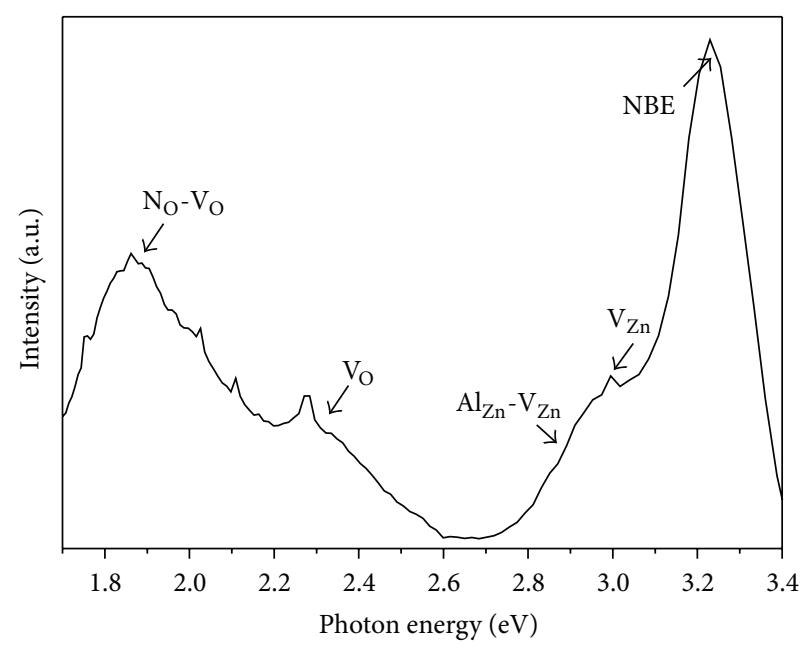

(b) Annealed $(\mathrm{Al}+\mathrm{N})$ codoped $\mathrm{ZnO}$

FIGURE 3: Room temperature PL spectra of the (a) as-deposited and (b) annealed ( $\mathrm{Al}+\mathrm{N})$ codoped $\mathrm{ZnO}$ films.

with a low resistivity of $5.6 \times 10^{-4} \Omega \mathrm{cm}$. Figures $2(\mathrm{a})$ and 2(b) show the room temperature PL (RTPL) spectra of the asdeposited and annealed $\mathrm{ZnO}$ films, respectively. For the PL spectrum of the as-deposited $\mathrm{ZnO}$ film, two broad emissions were observed. The UV and blue luminescence emerged from the near band edge emission (NBE) located at $3.24 \mathrm{eV}$ and the radiation associated with the native shallow defect transitions of zinc vacancy $\left(\mathrm{V}_{\mathrm{Zn}}\right)$ and $\mathrm{Zn}_{\mathrm{I}}$ at approximately
3.05 and $2.90 \mathrm{eV}$, respectively, while the deep level emission at green-yellow wavelength $(\sim 2.10 \mathrm{eV})$ was attributed to the native $\mathrm{V}_{\mathrm{O}}$ transition [31-33]. As the sample annealed at $700^{\circ} \mathrm{C}$ under oxygen ambient, the radiative transitions that resulted from the above-mentioned native defects almost were absent in the PL spectrum, as shown in Figure 2(b), revealing the improvement on the crystal structure. The PL spectrum therefore was dominated by the NBE emission. The RTPL 


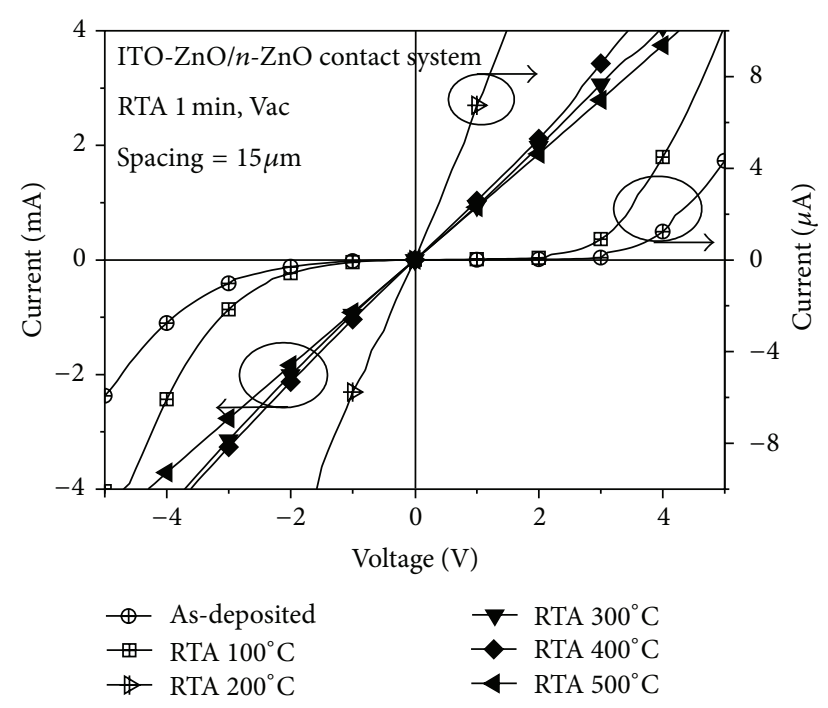

Figure 4: $I-V$ curves of the transparent ITO- $\mathrm{ZnO}$ cosputtered electrode contacts to the $n-\mathrm{ZnO}$ layer as a function of the annealing temperatures for $1 \mathrm{~min}$ under vacuum ambient.

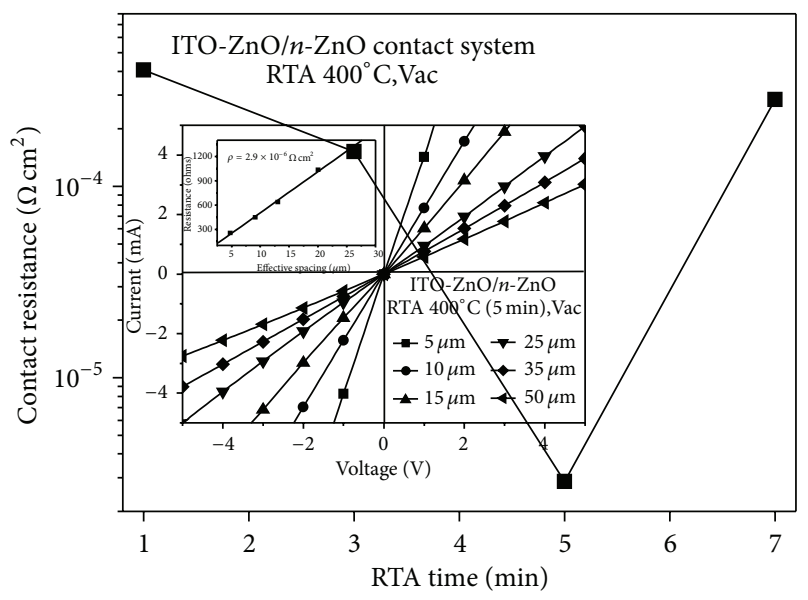

FIgURE 5: Specific contact resistance of the $400^{\circ} \mathrm{C}$-annealed ITO$\mathrm{ZnO} / \mathrm{n}-\mathrm{ZnO}$ contact system as a function of the annealing time under vacuum ambient (the inset figure shows the $I-V$ curves of the contact system annealed for $5 \mathrm{~min}$ ).

spectra of the as-deposited and annealed $(\mathrm{Al}+\mathrm{N})$ codoped $\mathrm{ZnO}$ films are showed in Figures 3(a) and 3(b). Compared to the as-deposited $\mathrm{ZnO}$ film, the spectrum of the as-deposited $(\mathrm{Al}+\mathrm{N})$ codoped $\mathrm{ZnO}$ film shown in Figure 3(a) composed a sharp UV emission, a weak blue emission, and a broad tail extending to long wavelength. In agreement with the reports [30, 34, 35], the UV and blue emissions approximately at $3.18 \mathrm{eV}$ and $2.86 \mathrm{eV}$ were, respectively, identified as the $\mathrm{NBE}$ and $\mathrm{Al}_{\mathrm{Zn}}-\mathrm{V}_{\mathrm{Zn}}$ radiative transitions. For the codoped film annealed at $450^{\circ} \mathrm{C}$ under nitrogen ambient, another radiation located at about $1.87 \mathrm{eV}$ predominated over the PL spectrum other than the NBE emission. This red luminescence was ascribed to be the $\mathrm{N}_{\mathrm{O}}-\mathrm{V}_{\mathrm{O}}$ radiative transition originated from the activation of the $\mathrm{N}_{\mathrm{O}}$ acceptors and thereby caused the codoped film exhibited $p$-type conduction.

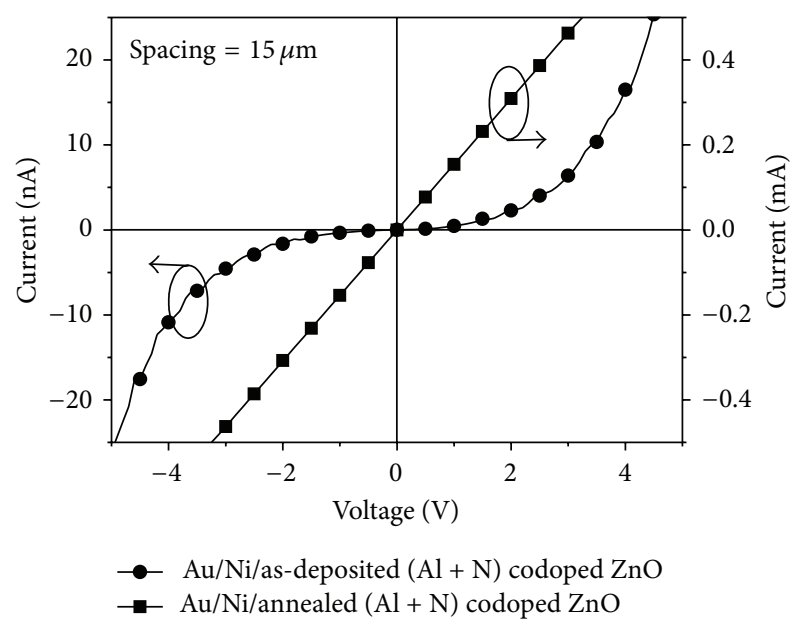

FIgURE 6: $I-V$ curves of the $\mathrm{Ni} / \mathrm{Au}$ metallic electrode contact to the as-deposited and annealed $(\mathrm{Al}+\mathrm{N})$ codoped $\mathrm{ZnO}$ film.

Figure 4 shows the $I-V$ curves of the transparent ITO$\mathrm{ZnO}$ cosputtered electrode contacts to $n$ - $\mathrm{ZnO}$ layer as a function of the annealing temperatures for $1 \mathrm{~min}$ under vacuum ambient, measured from the contact spacing of $15 \mu \mathrm{m}$. The as-deposited ITO- $\mathrm{ZnO} / n-\mathrm{ZnO}$ contact system exhibited the rectifying property, while a linear $I-V$ characteristic was achieved from the contact system annealed at $200^{\circ} \mathrm{C}$. The ohmic contact behavior of the ITO- $\mathrm{ZnO} / \mathrm{n}$ $\mathrm{ZnO}$ contact system was improved with increasing the annealed temperature and a lowest specific contact resistance approximately of $4.1 \times 10^{-5} \Omega \mathrm{cm}^{2}$ was obtained as the contact system annealed at $400^{\circ} \mathrm{C}$. The specific contact resistance of the $400^{\circ} \mathrm{C}$-annealed ITO- $\mathrm{ZnO} / n-\mathrm{ZnO}$ contact system as a function of the annealing time under vacuum ambient is highlighted in Figure 5 (theinset figure shows the $I-V$ curves of the contact system annealed for $5 \mathrm{~min}$ ). It can be seen that the specific contact resistance of the ITO- $\mathrm{ZnO} / n-\mathrm{ZnO}$ system was gradually improved with the annealing time increasing and then decreased significantly as the annealing time reached $7 \mathrm{~min}$. The ohmic contact resistance of the ITO- $\mathrm{ZnO} / n-\mathrm{ZnO}$ system, as shown in the inset figure, can be further optimized to $2.9 \times 10^{-6} \Omega \mathrm{cm}^{2}$ after annealing at $400^{\circ} \mathrm{C}$ for $5 \mathrm{~min}$ under vacuum ambient. The appearance of the homologous $\mathrm{Zn}_{2} \mathrm{In}_{2} \mathrm{O}_{5}$ compounds between the ITO$\mathrm{ZnO} / \mathrm{n}-\mathrm{ZnO}$ interfaces as a consequence of the outdiffusion of the oxygen atoms was demonstrated to be responsible for the ohmic contact optimization [36]. The $I-V$ curves of the $\mathrm{Ni} / \mathrm{Au}$ metallic electrode contact to the as-deposited and annealed $(\mathrm{Al}+\mathrm{N})$ codoped $\mathrm{ZnO}$ film, respectively, are showed in Figure 6. Since the as-deposited $(\mathrm{Al}+\mathrm{N})$ codoped $\mathrm{ZnO}$ film exhibited $n$-type conduction the $\mathrm{Ni} / \mathrm{Au}$ metallic system with a high work function contacted to the $n$-type (Al + $\mathrm{N})$ codoped $\mathrm{ZnO}$ film thus showed the rectifying property with low leakage current. By contrast, the $\mathrm{Ni} / \mathrm{Au}$ electrode contacted to the annealed $(\mathrm{Al}+\mathrm{N})$ codoped $\mathrm{ZnO}$ film which exhibited $p$-type conduction with a high hole concentration performed ohmic contact behavior with a specific contact resistance $2.7 \times 10^{-3} \Omega \mathrm{cm}^{2}$. With the aim to further improve the contact performance, the $\mathrm{Au} / \mathrm{Ni} / p-\mathrm{ZnO}$ contact system 


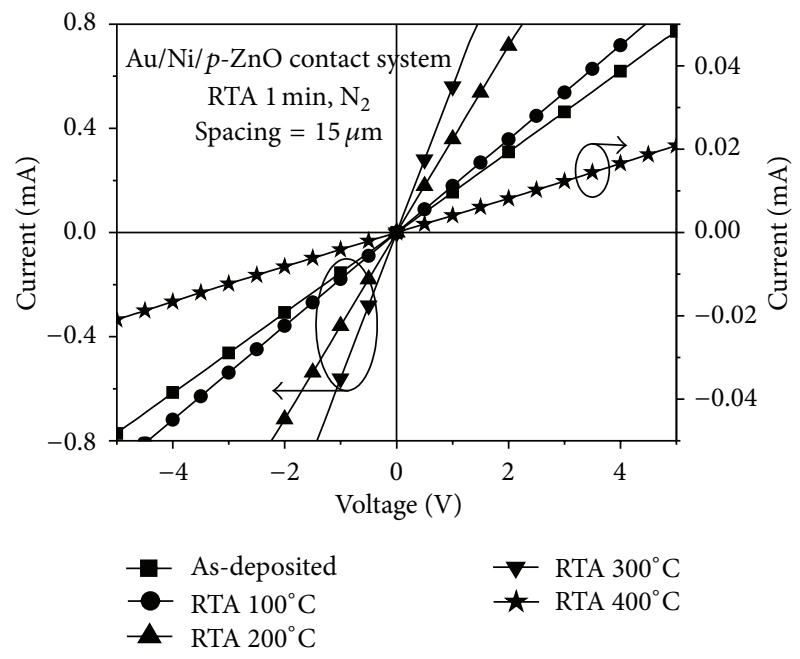

(a)

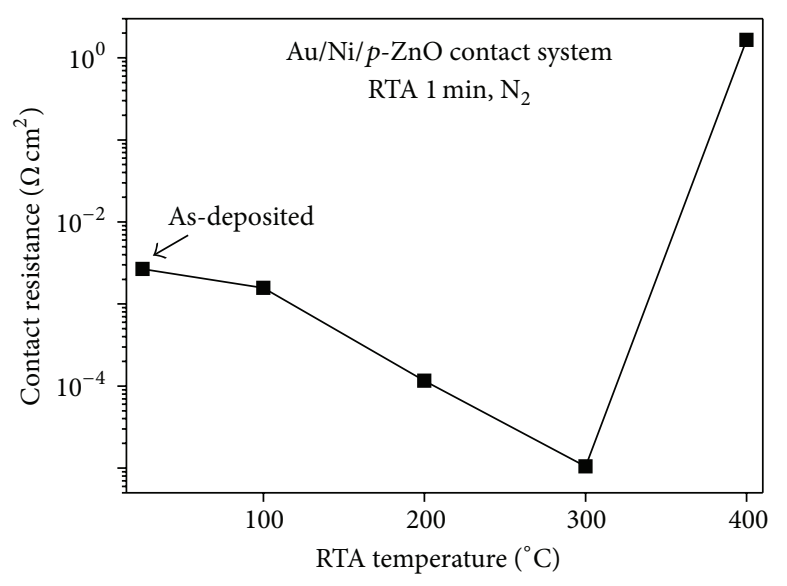

(b)

Figure 7: (a) $I-V$ characteristic and (b) specific contact resistance of the $\mathrm{Ni} / \mathrm{Au}$ metallic electrode contacts to the $p-\mathrm{ZnO}$ layer as a function of the annealing temperatures for $1 \mathrm{~min}$ under nitrogen ambient.

was processed by the RTA treatment. Figure 7(a) shows the $I-V$ characteristic of the $\mathrm{Ni} / \mathrm{Au}$ metallic electrode contacts to the $p$ - $\mathrm{ZnO}$ film as a function of the annealing temperatures for 1 min under nitrogen ambient. It can be found that the slope of these $I-V$ curves is increased with the annealing temperature raising, indicating the reduction in the contact resistance. The corresponding specific contact resistances of these annealed $\mathrm{Au} / \mathrm{Ni} / \mathrm{p}-\mathrm{ZnO}$ contact systems are illustrate in Figure 7(b). The lowest specific contact resistance of $3.5 \times$ $10^{-5} \Omega \mathrm{cm}^{2}$ was obtained from the $300^{\circ} \mathrm{C}$-anneald $\mathrm{Au} / \mathrm{Ni} / p$ $\mathrm{ZnO}$ contact system, and then this value was apparently increased to $1.7 \Omega \mathrm{cm}^{2}$ for the sample annealed at $400^{\circ} \mathrm{C}$ for 1 min under nitrogen ambient, revealing that the annealed temperature was crucial to optimize the $\mathrm{Ni} / \mathrm{Au}$ metallic electrode ohmic contact to the $p$ - $\mathrm{ZnO}$ film. An investigation on the interfaces between the metallic $\mathrm{Ni} / \mathrm{Au}$ and $p-\mathrm{ZnO}$ layer therefore was carried out to elucidate the evolutions of the specific contact resistance on the RTA treatment. Figures $8(\mathrm{a})-8(\mathrm{c})$, respectively, give the elemental depth profiles of the as-deposited, $300^{\circ} \mathrm{C}$-, and $400^{\circ} \mathrm{C}$-annealed $\mathrm{Au} / \mathrm{Ni} / \mathrm{p}-\mathrm{ZnO}$ contact system, conducted by AES measurements. For the asdeposited sample (Figure $8(\mathrm{a})$ ), the $\mathrm{Au}, \mathrm{Ni}$, and $\mathrm{p}$ - $\mathrm{ZnO}$ layers are well-defined and a little interdiffusion was observed from the $\mathrm{Au} / \mathrm{Ni}$ and $\mathrm{Ni} / p-\mathrm{ZnO}$ interfaces. The interlayer between $\mathrm{Ni}$ and $p$ - $\mathrm{ZnO}$ was presumed to form $p$-type $\mathrm{NiO}$ [37$40]$ and thus caused the as-deposited $\mathrm{Au} / \mathrm{Ni} / \mathrm{p}-\mathrm{ZnO}$ contact system to possess the ohmic contact behavior as shown in Figure 6. By contrast, in the case of the sample annealed at $300^{\circ} \mathrm{C}$, the outdiffusion of $\mathrm{Ni}$ and $\mathrm{O}$ through $\mathrm{Au}$ layer is clearly observed in Figure 8(b), indicating that the RTA treatment on the sample is greatly favorable to the formation of $p$-type $\mathrm{NiO}$ layer at the surface. Accordingly, an obvious reduction in the contact resistance as compared to the asdeposited sample was obtained from the $300^{\circ} \mathrm{C}$-annealed $\mathrm{Au} / \mathrm{Ni} / \mathrm{p}-\mathrm{ZnO}$ contact system. When the sample annealed at $400^{\circ} \mathrm{C}$, the outdiffusion of $\mathrm{O}$ is even more remarkable and no individual Ni layer can be observed in Figure 8(c). It is noteworthy that though the appearance of the $\mathrm{O}$ and $\mathrm{Ni}$ atoms is beneficial for the formation of $p$-type $\mathrm{NiO}$ and thus improved the $\mathrm{Au} / \mathrm{Ni} / p-\mathrm{ZnO}$ ohmic contact behavior, the oxygen atoms that outdiffuses from the $p-\mathrm{ZnO}$ layer surface also is likely to induce the $\mathrm{V}_{\mathrm{O}}$ donors and led to the decrease in the hole concentration at the $p$ - $\mathrm{ZnO}$ surface. As a result, apparently degradation on the specific contact resistance was obtained from the $400^{\circ} \mathrm{C}$-annealed $\mathrm{Au} / \mathrm{Ni} / p-\mathrm{ZnO}$ contact system which implied an exceeding outdiffusion of the $\mathrm{O}$ atoms at the $p-\mathrm{ZnO}$ surface. The $I-V$ characteristic of the $p$ $\mathrm{ZnO} / n-\mathrm{ZnO}$ homojunction structure using the $\mathrm{Ni} / \mathrm{Au}$ and ITO-ZnO ohmic contact electrode is illustrated in Figure 9. The ohmic contacts of the $\mathrm{Au} / \mathrm{Ni} / p-\mathrm{ZnO}$ and ITO- $\mathrm{ZnO} / n$ $\mathrm{ZnO}$ systems confirmed by the fairly linear $I-V$ relationship are given in the inset figure. A diode behavior was achieved from the $p-\mathrm{ZnO} / n-\mathrm{ZnO}$ homojunction structure prepared using the rf magnetron cosputtering system. The forward turn-on voltage appeared at about $1.44 \mathrm{eV}$ and yielded a rectifying ratio approximately of 20 at $\pm 2 \mathrm{~V}$. The ideality factor, $n$, extracted from the logarithmic plot of this $I-V$ curve by adopting the thermionic theory was about 3.8. Since such $p-\mathrm{ZnO} / n-\mathrm{ZnO}$ homojunction structure was achieved purely by sputtering technology, the dominant current transparent mechanism which resulted in the large deviation from the idea case $(n=1)$ thus was ascribed to be the defects in the interface and imperfections in the formation of the abrupt $p$ - $n$ homojunction originated from the ion-bombardment damage during film deposition. Accordingly, no electroluminescence was observed, possibly because of no radiative recombination emerging from the above-mentioned transitions at the interface of the homojunction structure which also showed evidence of the low forward turn-on voltage. 


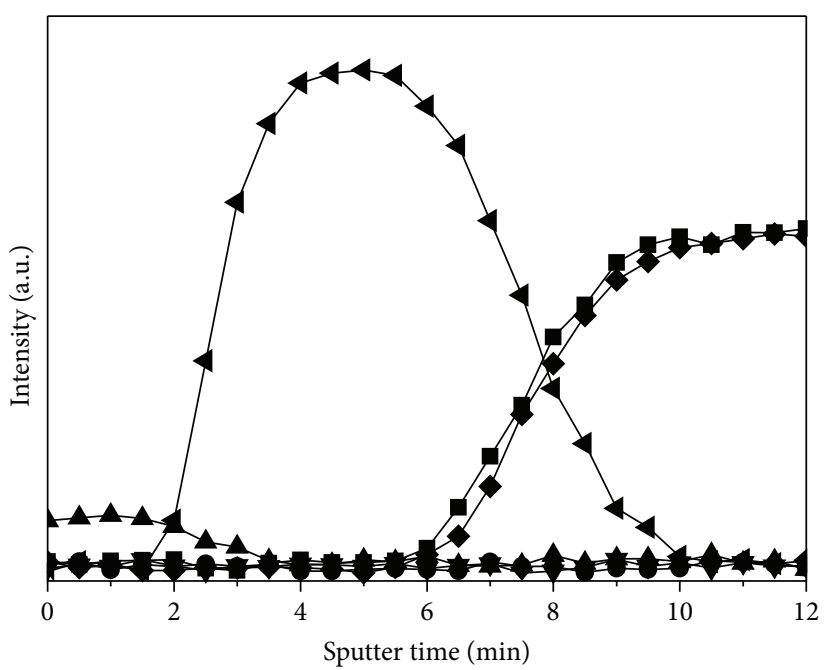

(a) As-deposited $\mathrm{Au} / \mathrm{Ni} / p-\mathrm{ZnO}$

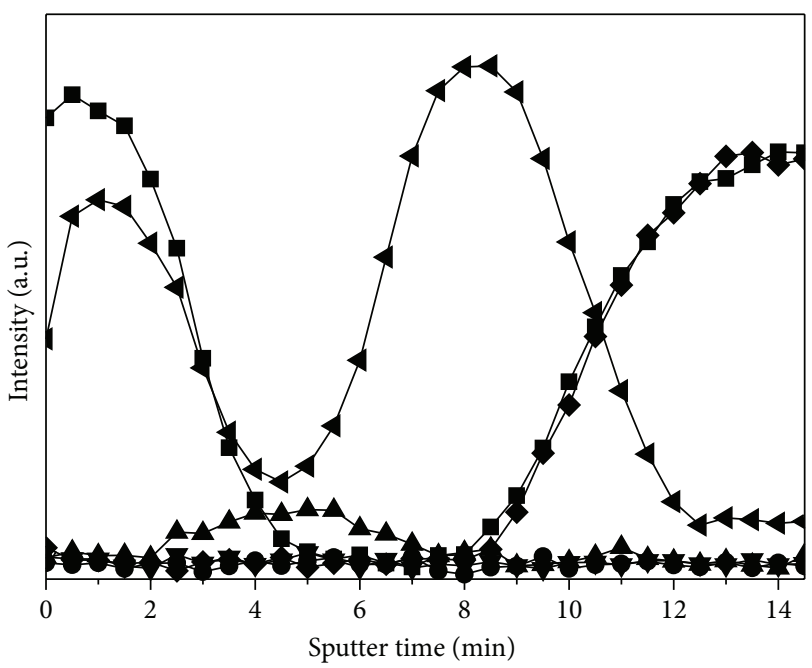

(b) $300^{\circ} \mathrm{C}$-annealed $\mathrm{Au} / \mathrm{Ni} / \mathrm{p}-\mathrm{ZnO}$

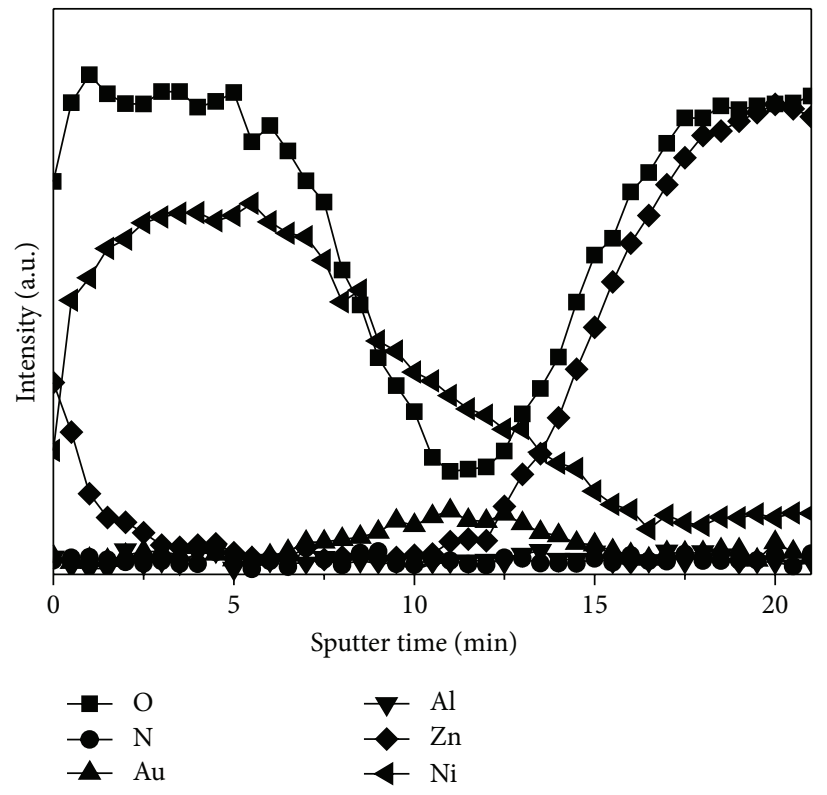

(c) $400^{\circ} \mathrm{C}$-annealed $\mathrm{Au} / \mathrm{Ni} / \mathrm{p}-\mathrm{ZnO}$

Figure 8: Elemental depth profiles of the (a) as-deposited, (b) $300^{\circ} \mathrm{C}$-annealed, and (c) $400^{\circ} \mathrm{C}$-annealed Au/ $\mathrm{Ni} / \mathrm{p}$ - $\mathrm{ZnO}$ contact systems, conducted by AES measurements.

\section{Conclusions}

The $n-\mathrm{ZnO}$ with dominated NBE emission and $p-\mathrm{ZnO}$ with dominated $\mathrm{NBE}$ emission and $\mathrm{N}_{\mathrm{O}}-\mathrm{V}_{\mathrm{O}}$ deep level radiation at $1.87 \mathrm{eV}$ was produced using the rf magnetron cosputtering system, followed by an adequate annealing process. For the transparent ITO- $\mathrm{ZnO} / n-\mathrm{ZnO}$ contact system annealed at $400^{\circ} \mathrm{C}$ for $1 \mathrm{~min}$ under vacuum ambient, the specific contact resistance was optimized to $2.9 \times 10^{-6} \Omega \mathrm{cm}^{2}$ due to the formation of the homologous $\mathrm{Zn}_{2} \mathrm{In}_{2} \mathrm{O}_{5}$ compounds associated with the outdiffusion of the oxygen atoms at the $n$ - $\mathrm{ZnO}$ layer surface. By contrast, the $\mathrm{Au} / \mathrm{Ni} / p-\mathrm{ZnO}$ contact system was optimized at a specific contact resistance of
$3.5 \times 10^{-5} \Omega \mathrm{cm}^{2}$ after annealing at $300^{\circ} \mathrm{C}$ for $1 \mathrm{~min}$ under nitrogen ambient. The mechanism responsible for the improvement of the $\mathrm{Au} / \mathrm{Ni} / \mathrm{p}-\mathrm{ZnO}$ contact system by an RTA treatment was attributed to the $p-\mathrm{NiO}$ interlayer formed between $\mathrm{Ni}$ and $p$ - $\mathrm{ZnO}$ interface, whereas the degradation on the contact resistance was ascribed to be the reduction in the hole carriers at the $p-\mathrm{ZnO}$ surface as a consequence of the considerable outdiffusion of the oxygen atoms. By taking advantage of these ohmic contacts' behavior, a quality diode performance with a forward turn-on voltage of $1.44 \mathrm{eV}$ and a reverse current of $1.1 \times 10^{-5} \mathrm{~A}$ at $-2 \mathrm{~V}$ was therefore obtained from the $p-\mathrm{ZnO} / n-\mathrm{ZnO}$ homojunction structure prepared purely using the rf magnetron cosputtering system. 


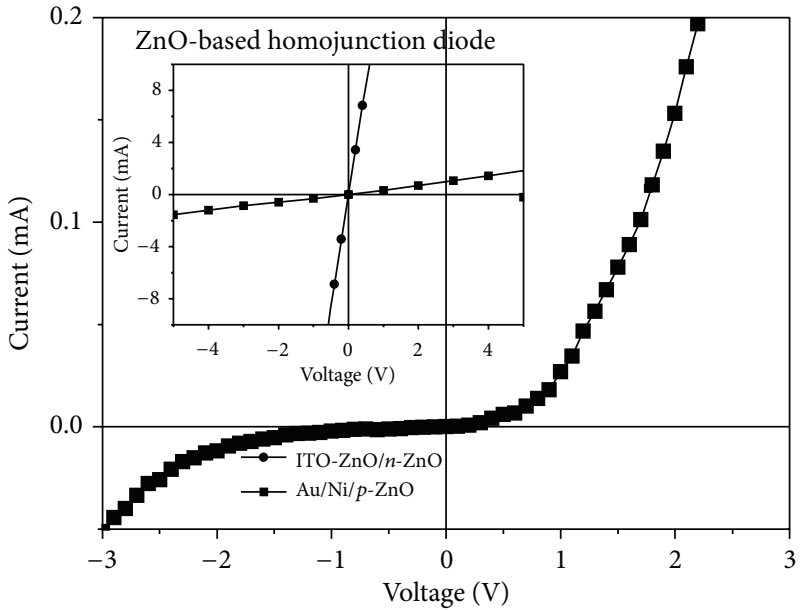

FIgURE 9: $I-V$ characteristic of the $p-\mathrm{ZnO} / n-\mathrm{ZnO}$ homojunction structure (the ohmic contacts of the $\mathrm{Au} / \mathrm{Ni} / \mathrm{p}-\mathrm{ZnO}$ and ITO- $\mathrm{ZnO} / n-$ $\mathrm{ZnO}$ systems are given in the inset figure).

\section{Conflict of Interests}

The authors declare that there is no conflict of interests regarding the publication of this paper.

\section{Acknowledgments}

This work was supported by the National Science Council and Industrial Technology Research Institute (ITRI South) under NSC 103-2221-E-150-024 and no. B200-103AE1. The authors also acknowledged the fund support by Asia Tree Technol. Co., Ltd.

\section{References}

[1] Y. Zhao, P. Deng, Y. Nie et al., "Biomolecule-adsorptiondependent piezoelectric output of $\mathrm{ZnO}$ nanowire nanogenerator and its application as self-powered active biosensor," Biosensors and Bioelectronics, vol. 57, pp. 269-275, 2014.

[2] M. Xu, Q. Li, Y. Ma, and H. Fan, "Ni-doped ZnO nanorods gas sensor: enhanced gas-sensing properties, AC and DC electrical behaviors," Sensors and Actuators B: Chemical, vol. 199, pp. 403409, 2014

[3] X. Fang, Y. Li, S. Zhang, L. Bai, N. Yuan, and J. Ding, “The dye adsorption optimization of $\mathrm{ZnO}$ nanorod-based dye-sensitized solar cells," Journal of Solar Energy Engineering, vol. 105, pp. 1419, 2014.

[4] X. Gu, M. Zhang, F. Meng, X. Zhang, Y. Chen, and S. Ruan, "Influences of different interdigital spacing on the performance of UV photodetectors based on $\mathrm{ZnO}$ nanofibers," Applied Surface Science, vol. 307, pp. 20-23, 2014.

[5] K. Ul Hasan, M. O. Sandberg, O. Nur, and W. Willander, "ZnO/polyfluorene hybrid LED on an efficient hole-transport layer of graphene oxide and transparent graphene electrode," Advanced Optical Materials, vol. 2, pp. 326-330, 2014.

[6] H. Hosono, H. Ohta, K. Hayashi, M. Orita, and M. Hirano, "Near-UV emitting diodes based on a transparent $p-n$ junction composed of heteroepitaxially grown $\mathrm{p}-\mathrm{SrCu}_{2} \mathrm{O}_{2}$ and n-Zno,"
Journal of Crystal Growth Part 1, vol. 237-239, no. 1-4, pp. 496$502,2002$.

[7] S. S. Jeong, A. Mittiga, E. Salza, A. Masci, and S. Passerini, "Electrodeposited $\mathrm{ZnO} / \mathrm{Cu}_{2} \mathrm{O}$ heterojunction solar cells," Electrochimica Acta, vol. 53, no. 5, pp. 2226-2231, 2008.

[8] S. H. Lee, X. Zhang, B. Smith, S. S. Seo, Z. W. Bell, and J. Xu, "ZnO-ZnTe nanocone heterojunctions," Applied Physics Letters, vol. 96, Article ID 193116, 2010.

[9] J. Kong, S. Chu, M. Olmedo, L. Li, Z. Yang, and J. Liu, "Dominant ultraviolet light emissions in packed $\mathrm{ZnO}$ columnar homojunction diodes," Applied Physics Letters, vol. 93, no. 13, Article ID 132113, 2008.

[10] J. Huang, S. Chu, J. Kong et al., "ZnO p-n homojunction random laser diode based on nitrogen-doped p-type nanowires," Advanced Optical Materials, vol. 1, no. 2, pp. 179-185, 2013.

[11] K. Y. Ko, H. Kang, J. Park et al., "ZnO homojunction coreshell nanorods ultraviolet photo-detecting diodes prepared by atomic layer deposition," Sensors and Actuators A: Physical, vol. 210, pp. 197-204, 2014.

[12] Y. K. Tseng, M. C. Hung, S. L. Su, and S. K. Li, "Using the hydrothermal method to grow $p$-type $\mathrm{ZnO}$ nanowires on $\mathrm{Al}$ doped $\mathrm{ZnO}$ thin film to fabricate a homojunction diode," Journal of Nanoscience and Nanotechnology, vol. 14, no. 10, pp. 7907-7910, 2014.

[13] L. Balakrishnan, P. Premchander, T. Balasubramanian, and N. Gopalakrishnan, "AlN codoping and fabrication of $\mathrm{ZnO}$ homojunction by RF sputtering," Vacuum, vol. 85, no. 9, pp. 881886, 2011.

[14] I. Y. Y. Bu, "Room temperature deposition of graded $\mathrm{ZnO}$ homojunction from a single sputter target," Superlattices and Microstructures, vol. 64, pp. 213-219, 2013.

[15] D. S. Liu, C. S. Sheu, and C. T. Lee, "Aluminum-nitride codoped zinc oxide films prepared using a radio-frequency magnetron cosputtering system," Journal of Applied Physics, vol. 102, no. 3, Article ID 033516, 2007.

[16] T. E. Murphy, J. O. Blaszczak, K. Moazzami, W. E. Bowen, and J. D. Phillips, "Properties of electrical contacts on bulk and epitaxial n-type ZnO," Journal of Electronic Materials, vol. 34, no. 4, pp. 389-394, 2005.

[17] S. H. Kim, K. K. Kim, S. J. Park, and T. Y. Seong, "Thermally stable and low resistance Re/Ti/Au ohmic contacts to n-ZnO," Journal of the Electrochemical Society, vol. 152, no. 3, pp. G169G172, 2005.

[18] H. Sheng, N. W. Emanetoglu, S. Muthukumar, B. V. Yakshinskiy, $\mathrm{S}$. Feng, and $\mathrm{Y}$. $\mathrm{Lu}$, "Ta/Au ohmic contacts to n-type $\mathrm{ZnO}$," Journal of Electronic Materials, vol. 32, no. 9, pp. 935-938, 2003.

[19] B. S. Kang, J. J. Chen, F. Ren et al., "ITO/Ti/Au Ohmic contacts on $n$-type ZnO," Applied Physics Letters, vol. 88, no. 18, Article ID 182101, 2006.

[20] H. Y. Lee, C. T. Su, B. K. Wu, W. L. Xu, Y. J. Lin, and M. Y. Chem, "Fabrication and properties of indium tin oxide/ZnO schottky photodiode with hydrogen peroxide treatment," Japanese Journal of Applied Physics, vol. 50, no. 8, Article ID 088004, 2011.

[21] D. J. King, L. Zhang, J. C. Ramer, S. D. Hersee, and L. F. Lester, "Temperature behavior of $\mathrm{Pt} / \mathrm{Au}$ ohmic contacts to $\mathrm{p}-\mathrm{GaN}$," MRS Proceedings, vol. 468, article 421, 1997.

[22] J. K. Kim, J. L. Lee, J. W. Lee, H. E. Shin, Y. J. Park, and T. Kim, "Low resistance $\mathrm{Pd} / \mathrm{Au}$ ohmic contacts to $p$-type $\mathrm{GaN}$ using surface treatment," Applied Physics Letters, vol. 73, no. 20, Article ID 2953, 1998. 
[23] J. K. Ho, C. S. Jong, C. C. Chiu, C. N. Huang, C. Y. Chen, and K. K. Shih, "Low-resistance ohmic contacts to p-type GaN," Applied Physics Letters, vol. 74, article 1275, 1999.

[24] J. C. Jang, I. S. Chang, H. K. Kim, T. Y. Seong, S. Lee, and S. J. Park, "Low-resistance Pt/Ni/Au ohmic contacts to p-type GaN," Applied Physics Letters, vol. 74, no. 1, p. 70, 1999.

[25] H. K. Cho, T. Hossain, J. W. Bae, and I. Adesida, "Characterization of $\mathrm{Pd} / \mathrm{Ni} / \mathrm{Au}$ ohmic contacts on $\mathrm{p}-\mathrm{GaN}$," Solid-State Electronics, vol. 49, no. 5, pp. 774-778, 2005.

[26] S. H. Kang, D. K. Hwang, and S. J. Park, "Low-resistance and highly transparent $\mathrm{Ni}$ /indium-tin oxide ohmic contacts to phosphorous-doped p-type ZnO," Applied Physics Letters, vol. 86, no. 21, Article ID 211902, 2005.

[27] J.-M. Lee, K. K. Kim, H. Tampo, A. Yamada, and S. Niki, “Ohmic contact to phosphorous-doped $\mathrm{ZnO}$ using $\mathrm{Pt} / \mathrm{Ni} / \mathrm{Au}$ for $\mathrm{p}-\mathrm{n}$ homojunction diode," Journal of the Electrochemical Society, vol. 153, no. 12, pp. G1047-G1050, 2006.

[28] G. Hu, H. Gong, and E. F. Chor, "Ohmic contact properties and annealing effect for $\mathrm{Au} / \mathrm{Ni}$ on p-Type P-Doped $\mathrm{ZnO}$," Journal of the Electrochemical Society, vol. 156, no. 9, pp. H740-H743, 2009.

[29] D.-S. Liu, C.-H. Lin, F.-C. Tsai, and C.-C. Wu, "Microstructure investigations of indium tin oxide films cosputtered with zinc oxide at room temperature," Journal of Vacuum Science \& Technology A, vol. 24, no. 3, p. 694, 2006.

[30] S. L. Yao, J. D. Hong, C. T. Lee, C. Y. Ho, and D. S. Liu, "Determination of activation behavior in annealed Al-N codoped $\mathrm{ZnO}$ Films," Journal of Applied Physics, vol. 109, no. 10, Article ID 103504, 2011.

[31] B. Lin, Z. Fu, and Y. Jia, "Green luminescent center in undoped zinc oxide films deposited on silicon substrates," Applied Physics Letters, vol. 79, no. 7, p. 943, 2001.

[32] Y. G. Wang, S. P. Lau, H. W. Lee et al., "Photoluminescence study of $\mathrm{ZnO}$ films prepared by thermal oxidation of $\mathrm{Zn}$ metallic films in air," Journal of Applied Physics, vol. 94, no. 1, pp. 354-358, 2003.

[33] X. Q. Wei, B. Y. Man, M. Liu, C. S. Xue, H. Z. Zhuang, and C. Yang, "Blue luminescent centers and microstructural evaluation by XPS and Raman in $\mathrm{ZnO}$ thin films annealed in vacuum, $\mathrm{N}_{2}$ and $\mathrm{O}_{2}$," Physica B: Condensed Matter, vol. 388, no. 1-2, pp. 145$152,2007$.

[34] S. B. Zhang, S. H. Wei, and A. Zunger, "Intrinsic n-type versus $p$ type doping asymmetry and the defect physics of $\mathrm{ZnO}$," Physical Review B, vol. 63, Article ID 075205, 2001.

[35] Z. P. Shan, S. L. Gu, K. P. Wu, S. M. Zhu, K. Tang, and Y. D. Zheng, "Induced changes on visible emission and conductive type in $\mathrm{N}$-doped $\mathrm{ZnO}$ films by rapid thermal process," Journal of Vacuum Science \& Technology A: Vacuum, Surfaces, and Films, vol. 28, no. 5, article 1115, 2010.

[36] C. C. Ho, L. W. Lai, C. T. Lee, K. C. Yang, B. T. Lai, and D. S. Liu, "Transparent cosputtered ITO-ZnO electrode ohmic contact to n-type $\mathrm{ZnO}$ for $\mathrm{ZnO} / \mathrm{GaN}$ heterojunction light-emitting diode," Journal of Physics D: Applied Physics, vol. 46, no. 31, Article ID 315102, 2013.

[37] D. Qiao, L. S. Yu, S. S. Lau, J. Y. Lin, H. X. Jiang, and T. E. Haynes, "A study of the $\mathrm{Au} / \mathrm{Ni}$ ohmic contact on $\mathrm{p}-\mathrm{GaN}$," Journal of Applied Physics, vol. 88, no. 7, Article ID 4196, 2000.

[38] J. M. Choi and S. Im, "Ultraviolet enhanced Si-photodetector using p-NiO films," Applied Surface Science, vol. 244, no. 1-4, pp. 435-438, 2005.

[39] E. Thimsen, A. B. F. Martinson, J. W. Elam, and M. J. Pellin, "Energy levels, electronic properties, and rectification in ultrathin $\mathrm{p}-\mathrm{NiO}$ films synthesized by atomic layer deposition,"
Journal of Physical Chemistry C, vol.116, no. 32, pp. 16830-16840, 2012.

[40] M. J. Ma, B. Lu, T. T. Zhou, Z. Z. Ye, J. G. Lu, and X. H. Pan, "Orientation dependent band alignment for $p-\mathrm{NiO} / n-\mathrm{ZnO}$ heterojunctions," Journal of Applied Physics, vol. 113, no. 16, Article ID 163704, 2013. 

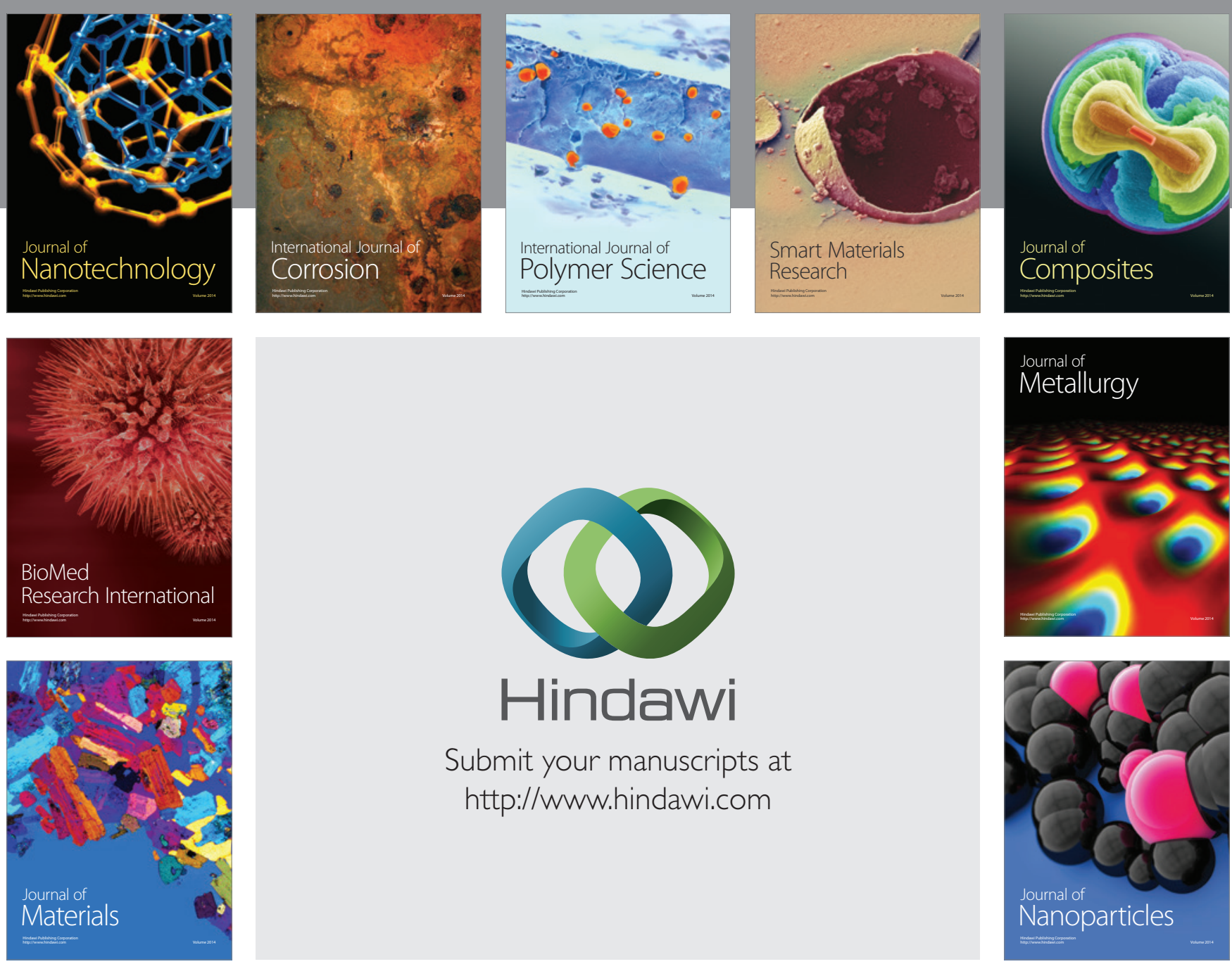

Submit your manuscripts at http://www.hindawi.com
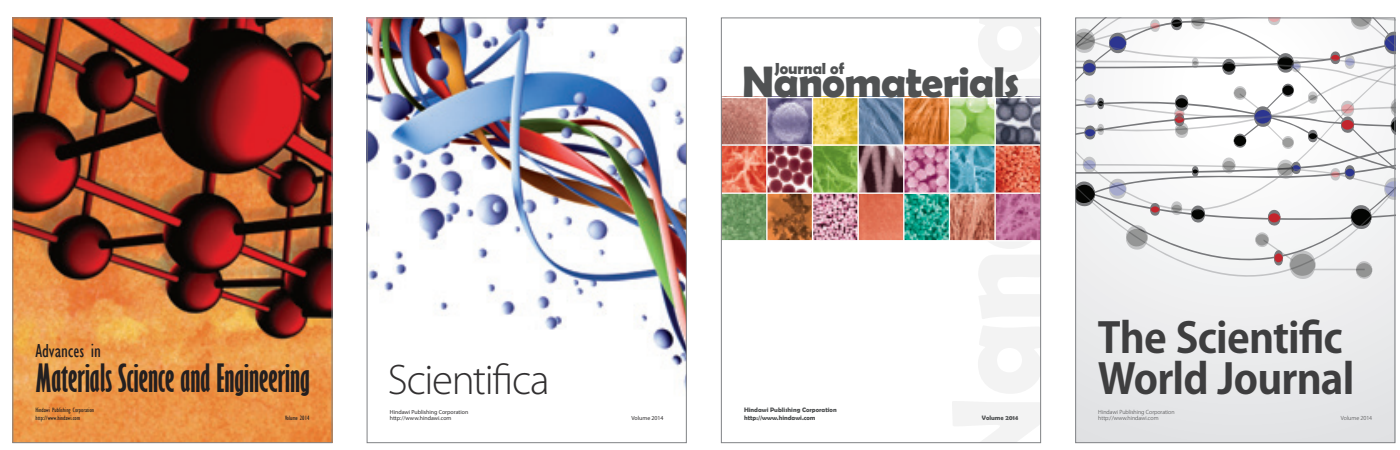

\section{The Scientific World Journal}
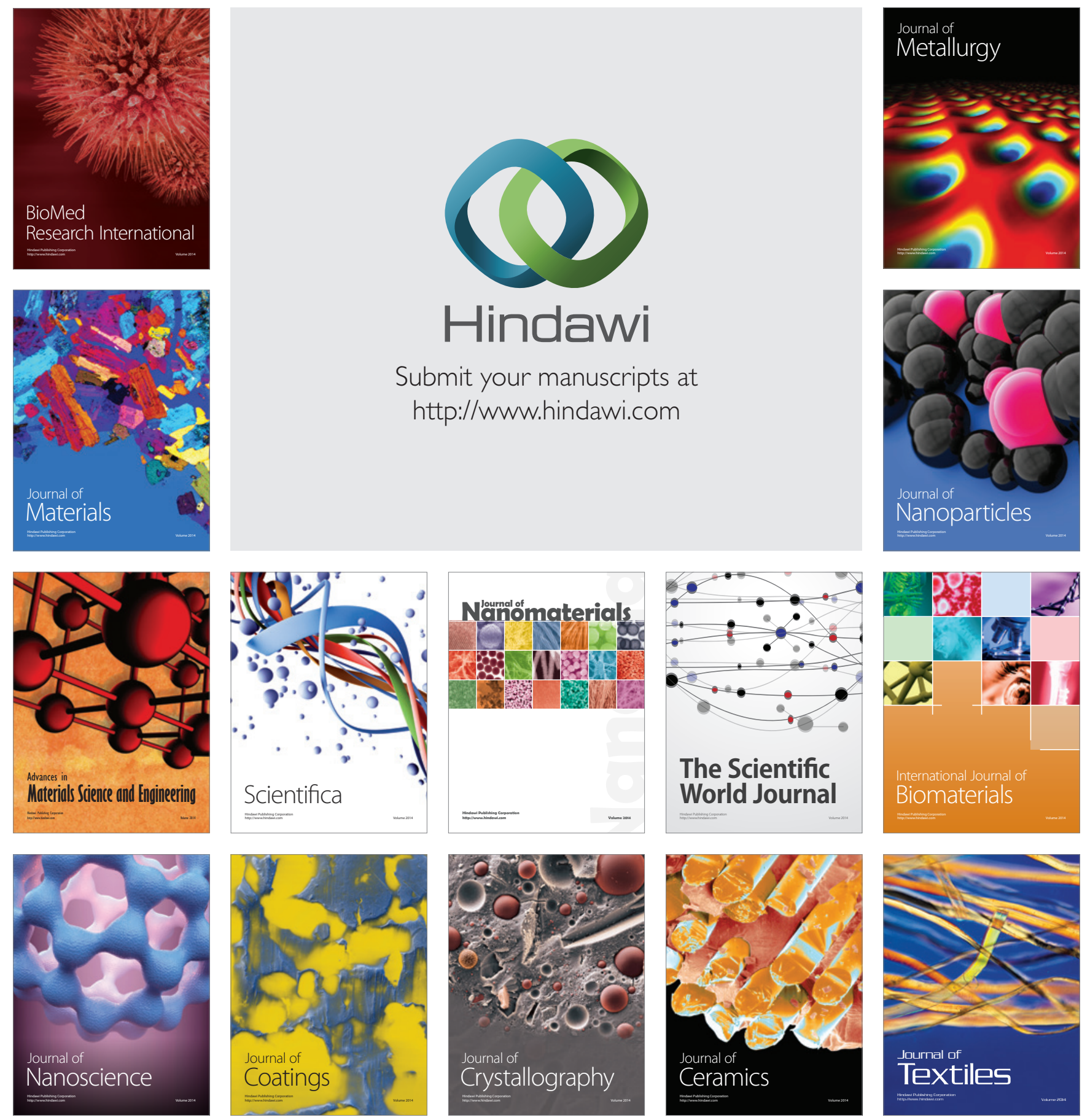